\title{
Yara Örtü Malzemesi Olarak Elektroeğrilmiş PCL/PHBV Membranların Hazırlanması ve Karakterizasyonu
}

\author{
İsmail Alper İŞOĞLU* \\ Abdullah Gül Üniversitesi, Biyomühendislik Bölümü, Kayseri \\ (ORCID: 0000-0001-6428-4207)
}

\begin{abstract}
Öz
Bu çalışmada, yara örtü malzemesi olarak polikaprolakton (PCL), poli(3-hidroksibütirik asit-ko-3-hidroksivalerik asit) (PHBV) ve ağırlıkça farklı oranlarda (100:0, 50:50, 75:25, 0:100) PCL/PHBV karışımları, farklı çözücüler (kloroform $\left(\mathrm{CHCl}_{3}\right), 1,1,1,3,3,3$-Hexfluoro-2-propanol (HFIP) ve bunların karışımları) kullanılarak elektroeğirme tekniği ile fibroz yapıda membranlar hazırlanmıştır. Tüm elektroeğrilmiş membranlar Fourier Dönüşümlü Kızılötesi Spektroskopisi (FT-IR), Diferansiyel Taramalı Kalorimetre (DSC) ve Taramalı Elektron Mikroskobu (SEM) ile yapı, morfoloji ve ısıl özellikleri açısından karakterize edilmiştir. Ayrıca, absorbsiyon testi ile sıvı tutma kapasiteleri analiz edilmiştir. Karakterizasyon basamağından sonra, seçilen membranların üzerine insan fibroblast hücreleri ekilmiş, in vitro hücre canlılık ve toksisite, MTT testi ile 24,48 ve 72 . saat için analiz edilmiştir. Membranların üzerine ekilen hücrelerin çoğalması 36, 72 ve 120. saat olmak üzere 3 farklı süre için incelenmiş, sonuçlar SEM ile gösterilmiştir. Elde edilen sonuçlar PCL/PHBV (75:25) karışım ile HFIP çözeltisinde elektroeğrilen membranın yara örtü malzemesi olarak kullanılabileceğini göstermiştir.
\end{abstract}

Anahtar kelimeler: PCL, PHBV, Elektroeğirme, Yara Örtü Malzemesi.

\section{The Preparation and Characterization of Electrospun PCL/PHBV Membranes as Wound Dressing Material}

\begin{abstract}
In this study, fibrous membranes of Polycaprolactone (PCL), Poly(3-hydroxybutyrate-co-3-hydroxyvalerate) (PHBV) and PCL/PHBV blends in different weight ratios (100:0, 50:50, 75:25, 0:100) were prepared using different solvents (chloroform $\left(\mathrm{CHCl}_{3}\right)$, 1,1,1,3,3,3-Hexafluoro-2-propanol (HFIP) and their blends) via electrospinning technique as wound dressing materials. Structural, morphological, and thermal characterizations of membranes were performed by Fourier Transform Infrared Spectroscopy (FT-IR), Scanning Electron Microscopy (SEM) and Differential Scanning Calorimetry (DSC), respectively. Moreover, the water-uptake capacity of the membranes were analyzed using absorption test. Following that, human fibroblast cells were seeded on the selected membranes and in vitro cell viability and toxicity were monitored by MTT assay for 24,48 and $72^{\text {th }}$ hours. The seeded cell proliferation on membranes was conducted for 36,72 and $120^{\text {th }}$ hours and the results were examined by SEM. The results of this study relieved that electrospun PCL/PHBV (75:25) blend membrane solved in HFIP can be used as wound dressing materials.
\end{abstract}

Keywords: PCL, PHBV, Electrospinning, Wound Dressing Material.

\section{Giriş}

Deri insan vücudunun en geniş organıdır ve vücudumuzu çepeçevre sararak diğer organlarımızı mekanik ve kimyasal diş etmenlerden ve özellikle mikrobiyal patojenlere karşı koruyan bir bariyer olarak görev yapmaktadır. Bir diğer önemli görevi ise vücut sıcaklığını ve hidrasyon seviyesini düzenlemektir [1-3]. Deri dokusu, doğrudan dış etmenlerle temas halinde olduğundan yaralanma ve yanma sonucu kolayca

\footnotetext{
*Sorumlu yazar: alper.isoglu@agu.edu.tr

Geliş Tarihi: 22.02.2019, Kabul Tarihi: 01.07.2019
} 
tahrip olmaktadır [4]. Özellikle geniş bir bölgede meydana gelen deri dokusu kayıpları, dünyada milyonlarca kişiyi etkileyen en önemli klinik problemler arasında yer almaktadır [5]. Hasarlı deri dokusunun iyileşmesi, dermal, epidermal ve bağışıklık sistemi hücreleri gibi çok farklı tipte hücrenin, ekstra sellülar matriksin, plazma türevli proteinler ve büyüme faktörlerinin birlikte etkili olduğu oldukça karmaşık ve interaktif bir süreçtir [6]. Otograftlar, allograftlar ve zenograftlar günümüzde kullanılan geleneksel yara örtü malzemeleridir. Ancak, bu malzemelerin donör bölge kısıtı, antijen özelliklerinin düşük olması, kullanım ömrü kısalı̆̆ı, düşük güç ve dayanım, ve enzimatik direnç gibi birçok dezavantaja sahip olduğu bilinmektedir [7-8]. Geleneksel yara örtü malzemelerinin yanında, doğal ve sentetik polimerlerden üretilen hücre büyümesini destekleyen, yüksek biyouyumluluğa sahip, güçlü ve dayanımı yüksek, ve kontrollü bozunma gibi üstün özelliklere sahip deri dokusu ikameleri de kullanılmaya başlanmıştır [9].

Son yıllarda, yara örtüsü hazırlanması amacıyla, kendiliğinden bir araya gelme, faz ayrımı, 1slak eğirme ve elektroeğirme gibi birçok farklı yöntem kullanılmakta, çok çeşitli, yeni ve modern yara örtü malzemeleri elde edilmektedir [10-11]. Elektroeğirme çok basit ve ucuz bir yöntem olmasına rağmen nanometre boyuttan mikrometre boyutuna kadar farklı çaplarda fiber yapıya sahip membran elde edilmesinde kullanılan çok etkili bir yöntem olarak karşımıza çıkmaktadır [12]. Elektroeğirme sistemi temel olarak yüksek güç kaynağı, polimer çözeltisinin yerleştirildiği kapiler tüp (iğne) ve topraklanmış toplayıcı olmak üzere üç temel üniteden oluşmaktadır. Bu yöntemde, güç kaynağı kullanılarak uygulanan yüksek gerilim sayesinde polimer çözeltisi iğnenin ucundan buhar jeti şeklinde zıt yüklü olan metal toplayıcıya doğru püskürtülmekte, yol boyunca çözücünün buharlaşması ile polimerin fiber yapıda toplayıcıda birikmesi amaçlanmaktadır [13]. Elektroeğirme yöntemi, esnek ve düşük maliyetli bir yöntem olması, kullanım kolaylığı sağlaması ve proses parametrelerinin ayarlanması ile istenilen boyutta (nano ya da mikro) fiber çaplarına sahip membran üretimine olanak sağlaması gibi önemli özelliklerinden dolayı son 20 yıl içerisinde global anlamda oldukça ilgi çekici bir yöntem olarak karşımıza çıkmaktadır [14].

Geleneksel yara örtü malzemeleri ile karşılaştırıldığında, elektroeğirme yöntemi ile elde edilen malzemelerin ayarlanabilir gözenek yapısı, hücre dışı matriksi oldukça yüksek oranda biyotaklit etmesi, sıv1 ve gaz geçirgenliği sağlaması, yara bölgesinin mikroçevresini nemli tutması ve yara izi oluşumunu azaltması gibi sıra dışı özelliklere sahip oldukları görülmektedir [15-16]. Bu özelliklerin yanı sıra, yüksek yüzey alanına sahip olmalarından dolayı hücre yapışması ve çoğalmasına olanak sağlamakta, yara bölgesine sıvı toplanmasının önüne geçmektedir [17-18]. Yara örtüsü, yenilenebilir tıp, doku mühendisliği ve ilaç salım sistemleri gibi birçok biyomedikal uygulamada elektroeğirme yöntemi ile uygun bir çözücü içerisinde çözünebilen çok çeşitli doğal ve sentetik polimerler kullanılarak hazırlanmış membranlar literatürde bilinmektedir [19].

Elektroeğirme tekniği kullanılarak yara örtü malzemesi üretimi için poli(kaprolakton) (PCL), poli( $\alpha \square$ hidroksi asitler), laktik asit, glikolik asit ve bunların kopolimerleri en sik kullanılan sentetik polimerler olarak bilinmektedir [20-22]. Yarı-kristalin yapiya sahip biyobozunur ve biyouyumlu bir polyester olan Amerika Birleşik Devletleri Gıda ve İlaç Kurumu (FDA) onaylı PCL, sahip olduğu mekanik ve yapısal özelliklerinden dolayı bu sentetik polimerler arasında en çok tercih edilen polimer olarak karşımıza çıkmaktadır [23]. Özellikle, PCL kullanılarak elde edilen elektroeğrilmiş membranlar, birbiriyle bağlantılı gözenekli yapıya sahip elastik morfoloji sayesinde gaz değişimine olanak sağlamakta ve yara bölgesindeki eksudatı absorblamaktadır. Ayrıca, bu elastik yapı yara bölgesinde hareket rahatlığı sağlamaktadır [24]. Ancak, yukarıda ifade edilen birçok özelliğine rağmen PCL membranların yara iyileşme sürecine etki eden bazı dezavantajları vardır. Özellikle, yara bölgesine kuvvetli şekilde tutunma eğilimi göstermektedirler. Bu durumda tamir olan yeni deri dokusunun zarar görmesine ve yara iyileşme sürecinin uzamasına neden olmaktadır (24). Bunun yanı sıra diğer alifatik polyesterlerde olduğu gibi yüksek hidrofobik özelliği PCL'nin yara örtü malzemesi olarak tek başına kullanımını sınırlamaktadır [25].

Polihidroksi alkonatlar (PHA), mikroorganizmalar tarafından üretilen biyobozunur doğal termoplastik alifatik polyesterlerdir ve yüksek biyouyumluluk özellikleri sebebiyle biyomalzeme olarak kullanılmaktadırlar [26]. Yapılan bilimsel çalışmalarda PHA'lar kullanılarak üretilen malzemelerin fibroblast, osteoblast, kondrosit, sinir ve kök hücre gibi çok farklı hücrelerin çoğalmasına olanak sağladığı gösterilmiştir. Ayrıca, özellikle fibroblast ve keratinosit hücreleri için polilaklatlar dahil diğer polimerlere oranla daha etkin olduğu gösterilmiştir [27-28]. 
Günümüzde gerçekleştirilen çalışmalarda, sentetik veya doğal polimerlerin karışım olarak kullanıldığ 1 elektroeğrilmiş membranlardan elde edilen yara örtü malzemelerinin sözü geçen polimerlerin tek başına kullanılmalarına kıyasla sinerjik bir etkisi olduğu ve yara iyileşme sürecine pozitif katkı sağladığı gösterilmiştir. Örneğin literatürde yer alan bir çalışmada Tohidi ve arkadaşları elektroeğrilmiş amoksilin yüklü halloysit nanokil içeren PLGA/kitosan membranlar hazırlamışlar ve yara örtüsü olarak kullanımını araştırmışlardır [16]. Martins ve arkadaşları, elektroeğrilmiş PCL/aminofonksiyonel tanen membranlar hazırlamışlar ve yara örtüsü olarak performansını değerlendirmişlerdir [25]. Adeli-Sardou ve arkadaşları elektroeğirme yöntemi ile PCL/jelatin membranlar hazırlamışlar, bu membran içerisine kına yaprağı ekstratı olan lawsone yüklemişler ve deri doku mühendisliği için doku iskelesi olarak kullanımını araştırmışlardır [29]. Ehtrami ve arkadaşları insülin içeren kitosan nanopartikül yüklü elektroeğrilmiş PCL/kollajen nanofibröz matrisleri potansiyel bir yara örtü malzemesi olarak denemişlerdir [30]. Bir başka çalışmada Veleirinho ve arkadaşları, nanofibröz PHBV/kitosan membran hazırlamışlar, hasarlı deri dokusu rejenerasyonu için etkisini incelemişlerdir [27]. Yuan ve arkadaşları, elektroeğrilmiş nanofibröz PHBV/keratin membranlar hazırlamışlar ve yeni bir yara örtü malzemesi olarak literatüre raporlamışlardır [15].

$\mathrm{Bu}$ çalışmada, elektroeğirme yöntemi kullanılarak PCL, PHBV ve farklı oranlarda PCL/PHBV karışımından membranlar hazırlanmış, yapısal, morfolojik ve 1 sıl karakterizasyonları gerçekleştirilmiştir. Karakterizasyon sonrası en uygun özelliklere sahip membranlara insan fibroblast hücreleri ekilmiş, in vitro hücre canlılık, toksisite ve hücre çoğalması çalışmaları yapılarak sonuçlar rapor edilmiştir.

\section{Materyal ve Metot}

\subsection{Materyal}

Polikaprolakton (PCL, Mw: $80 \mathrm{kDa}$ ) ve Poli(3-hidroksibütirik asit-ko-3-hidroksivalerik asit) (PHBV, Mw: $690 \mathrm{kDa}, 12 \%$ PHV içerikli) Aldrich'ten (ABD) satın alınmıştır. İnsan fibroblast hücreleri Erciyes Üniversitesi Genom ve Kök Hücre Merkezi (Kayseri, Türkiye) tarafından laboratuvarımıza hibe edilmiştir. Kullanılan diğer kimyasal ve çözücüler analitik kalitede olup, herhangi bir saflaştırma işlemine tabi tutulmadan satın alındıkları gibi kullanılmıştır.

\subsection{Metot}

\subsubsection{Elektroeğrilmiş PCL, PHBV ve PCL/PHBV karışım fibroz membranların hazırlanması}

PCL, PHBV ve PCL/PHBV karışımları ağırlıkça farklı oranlarda (100:0, 50:50, 75:25, 0:100) olacak şekilde kloroform $\left(\mathrm{CHCl}_{3}\right)$, kloroform-1,1,1,3,3,3-hekzafluro-2-propanol $\left(\mathrm{CHCl}_{3}\right.$-HFIP) ve sadece HFIP içerisinde çözülerek hacimce \%15'lik elektroeğirme çözeltileri hazırlanmıştır. Her bir çözelti ayrı ayrı iç çapı $14.53 \mathrm{~mm}$ olan ve $21 \mathrm{G}$ iğne ucuna sahip $10 \mathrm{~mL}$ 'lik şırıngalara alınmış ve otomatik programlanabilir şırınga pompasına (NE-1000, ABD) yerleştirilmiştir. Elektroeğirme prosesi, topraklanmış toplayıcı ve iğne ucu arasında gerekli elektrik potansiyel oluşturması için bir yüksek gerilim ünitesi (Inevenso NE100, Türkiye) kullanılarak, akış hızı $1 \mathrm{~mL} / \mathrm{h}$ ve uygulanan gerilim $15 \mathrm{kV}$ olacak şekilde sistem ayarlanmıştır. Toplayıcı ve iğne ucu arasındaki mesafe $15 \mathrm{~cm}$ 'ye set edilmiştir.

\subsubsection{Yapısal ve Morfolojik Karakterizasyon}

\section{FT-IR Analizi}

Elektroeğrilmiş PCL, PHBV ve PCL/PHBV membranlarının FT-IR analizi Thermo Scientific Nicolet 6700 FT-IR Spektrometre kullanılarak 400-4000 $\mathrm{cm}^{-1}$ aralığında gerçekleştirilmiştir.

\section{DSC Analizi}

Elektroeğrilmiş membranların ısıl analizleri, DSC (Perkin Elmer, ABD) ile $10{ }^{\circ} \mathrm{C} \mathrm{min}{ }^{-1}$ ssıtma hızı ve 0 'dan $200{ }^{\circ} \mathrm{C}$ derece sıcaklık aralığında azot ortamında gerçekleştirilmiş, termal döngü birbirini takip eden bir 1sıtma ve bir soğutma taraması ile gerçekleştirilmiş̧ir. 


\section{Morfolojik Çalışmalar}

Elektroeğrilmiş membranların morfolojik özellikleri taramalı elektron mikroskobu (SEM) kullanılarak araştırılmıştır. Bunun için öncesinde membranlar vakum altında ince bir altın tabaka ile kaplanmış (Quorum Q150RES, Birleşik Krallık) ve daha sonra SEM görüntüleri alınmıştır (Carl Zeiss EVO LS10, Almanya). SEM görüntüleri üzerinden JMicroVision 1.2.7 (Ulusal Sağl1k Örgütü, ABD) programı kullanılarak farklı noktalardaki rastgele seçilen fiberlerin çapları ölçülmüş, membranlara ait fiberlerin ortalama çapları standart sapmaları ile birlikte sunulmuştur.

\section{Absorbsiyon Testi}

Yara sıvısını taklit etmek için "Pseudo Extra Cellular Fluid (PECF)" çözeltisi hazırlanmıştır. Bunun için, sodyum klorür $(\mathrm{NaCl})$, potasyum klorür $(\mathrm{KCl})$, sodyum bikarbonat $\left(\mathrm{NaHCO}_{3}\right)$ ve dipotasyum fosfat $\left(\mathrm{K}_{2} \mathrm{HPO}_{4}\right)$ distile su içerisinde çözülmüş, çözeltinin pH’1 8 olarak ayarlanmıştır. Elektroeğirme yöntemi ile hazırlanan PCL/PHBV (75:25, HFIP) membran ile çözücü uzaklaştırma yöntemi ile hazırlanan PCL/PHBV (75:25, HFIP) membran karşılaştırılmıştır. Her iki membran 1x1.5 cm² olarak kesilmiş ve ilk tartımları alınmıştır. Daha sonra bu membranlar, PECF içeren petri kapları içerisine yerleştirilmiş ve 24 saat $37{ }^{\circ} \mathrm{C}$ inkübator içerisinde bekletilmiştir. Beklemenin ardından fazlalık olan PECF çözeltileri petri kabından uzaklaştırılarak membranlar tekrar tartılmıştır. Yüzde absorbsiyon miktarı aşağıdaki eşitlik ile hesaplanmıştır [31].

$$
\% \mathrm{~W}_{\mathrm{C}}=\left(\mathrm{W}-\mathrm{W}_{0}\right) / \mathrm{W}_{0} \times 100
$$

Burada, $\mathrm{W}_{0}$ membranların ilk kuru tartımı, $\mathrm{W}$ ıslak iken tartımıdır.

\subsection{Hücre Kültürü Çalışmaları}

\section{In vitro Hücre Kültürü ve Sitotoksisite Testi}

İnsan fibroblast hücreleri $10 \mathrm{~cm}^{2}$ doku kültür kabında, $4.5 \mathrm{mg} / \mathrm{ml}$ glikoz, $\% 10$ fetal sığır serumu (FBS) ve \%1 penisilin ve streptomisin içeren $10 \mathrm{~mL}$ DMEM besi yerinde çoğaltılmıştır. Besi yeri her gün değiştirilmiş ve hücreler $\% 5^{\prime}$ lik $\mathrm{CO}_{2}$ inkübatöründe $37{ }^{\circ} \mathrm{C}$ tutulmuşlardır. Morfolojik ve yapısal karakterizasyon sonrası en uygun özelliklere sahip olduğu belirlenen elektroeğrilmiş PCL/PHBV (75:25, HFIP) membranı in vitro hücre kültür çalışmaları için seçilmiştir. Seçilen membranın toksisitesi MTT testi ile 24, 48 ve 72 . saatlerde ölçülmüştür. Bu amaçla, membran çapı $2,5 \mathrm{~cm}$ olacak şekilde dairesel olarak kesilmiş ve \% 70'lik etanol içerisinde steril edildikten sonra 96'lık hücre kuyucuklarına yerleştirilmişlerdir. Yerleştirilen membranlar üzerine hücre sayısı $1 \times 10^{4}$ olacak şekilde insan fibroblast hücreleri ekilmiştir. Kuyucuklarda yer alan besi yeri $20 \mu 1$ MTT çözeltisi ve $100 \mu 1$ kültür besi yeri ile değiştirilmiştir. Daha sonra hücreler $37^{\circ} \mathrm{C}$ ve 4 saat boyunca inkübe edilmiştir. İnkübasyon sonrası, tüm besi yeri özenle uzaklaştırılmış formazan kristalleri DMSO'da çözünmüş, $490 \mathrm{~nm}$ absorbans değerinde ölçüm gerçekleştirilmiştir (Thermo Scientific Varioskan Lux, ABD).

\section{Hücre Çoğalması Çalışması}

Seçilen elektroeğrilmiş PCL/PHBV (75:25, HFIP) membran çap $2,5 \mathrm{~cm}$ olacak dairesel olarak kesilmiş ve \%70'lik etanol içerisinde 1 saat ve sonrası UV altında bekletilmek suretiyle steril edildikten sonra 96'llk kuyucuklara yerleştirilmiştir. Her bir membran üzerine hücre yoğunluğu $1 \times 10^{4}$ olacak şekilde insan fibroblast hücreleri ekilmiş, $37^{\circ} \mathrm{C}$ sıcaklıkta $\% 5^{\prime}$ lik $\mathrm{CO}_{2}$ ortamında inkübe edilmişlerdir. Önceden belirlenen 36, 72 ve 120. saat sonunda inkübe edilen hücreler PBS çözeltisi ile 3 kez yıkanmış, membranın üzerine tutunmayan hücrelerin uzaklaştırılması sağlanmıştır. Daha sonra hacimce \% $2.5^{\prime}$ luk gluter aldehit çözeltisinde 2 saat fikse edilmiş, \%30, 50, 70, 90 ve 100 kademeli etanol çözeltisi içerinde 10 'ar dakika dehidrade edilmişlerdir. Bu işlemlerin ardından kurutulan membranlarda hücre çoğalmaları SEM görüntüleri alınarak gösterilmiştir. 


\section{Bulgular ve Tartışma}

\subsection{FT-IR}

Elektroeğrilmiş PCL, PHBV ve PCL/PHBV karışım membranların yapısal analizleri FT-IR ile gösterilmiştir. Şekil 1'de, membranlara ait FT-IR spektrumları karşılaştırılmalı olarak sunulmuştur. Spektrumlarda yer alan, $1750-1710 \mathrm{~cm}^{-1}$ arasında görülen geniş pikin nedeni hem PCL hem de PHBV'de bulunan $-\mathrm{C}=\mathrm{O}$ ester karbonil grubuna ait gerilimdir. $2950-2860 \mathrm{~cm}^{-1}$ arasında gözlenen pikler polimerlerin yapılarında yer alan CH geriliminden kaynaklanmaktadır. $1238 \mathrm{~cm}^{-1} \mathrm{ve} 1164 \mathrm{~cm}^{-1}$ civarında görülen piklerin nedeni sırasıyla polimer zincirindeki asimetrik -C-O-C- gerilimi ve -C-C- gerilimidir. PCL/PHBV karışımına ait spektrum incelendiğinde piklerin yoğunluklarının arttığı değerlendirilmiştir. Ayrıca, yine karışım için piklerde herhangi bir kayma gözlenmemiş bunun da PCL ve PHBV molekülleri arasında spesifik bir etkileşim olmadığı belirtilmiş̧ir [32].

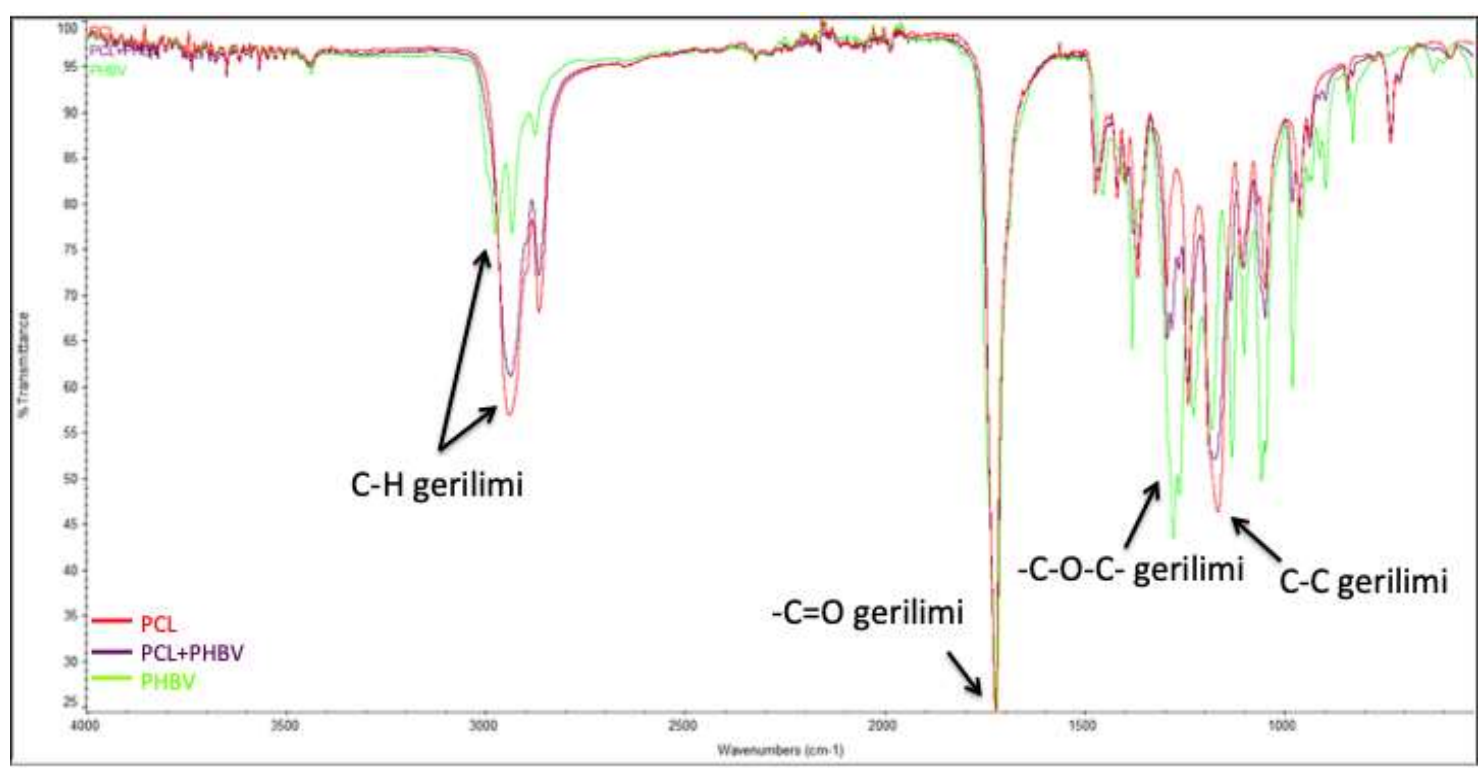

Şekil 1. Elektroeğrilmiş PCL, PHBV ve PCL/PHBV karışım membranlarına ait FT-IR spektrumları

\subsection{DSC}

Biyobozunur polimerlerde kristal yapısı (kristalinite yüzdesi, morfolojisi, vb.) materyallerin mekanik, 1sı1, kimyasal ve bozunma davranışlarını etkileyen önemli özelliklerinden biridir. Bu kapsamda elektroeğrilmiş PCL, PHBV ve PCL/PHBV (75:25, HFIP) karışım membranlarının DSC termogramları çekilmiş ve elde edilen termogramlar Şekil 2'de verilmiştir. Isıl geçişleri temsil eden erime sicaklikları $(\mathrm{Tm})$ grafikler üzerinde sayısal olarak gösterilmiştir. Elektroeğrilmiş PCL membran için Tm, $59.84{ }^{\circ} \mathrm{C}$ bulunmuştur. PCL için yapılan önceki çalışmalarda erime sıcaklığının $60^{\circ} \mathrm{C}$ derece civarı olarak raporlanmıştır. Dolayısıyla bulunan değerler literatürle uyumludur [33]. Elektroeğrilmiş PHBV için $144.71{ }^{\circ} \mathrm{C}\left(\mathrm{Tm}_{1}\right)$ ve $155.39^{\circ} \mathrm{C}\left(\mathrm{Tm}_{2}\right)$ derece olmak üzere iki adet erime sicaklık değerleri literatürde de verildiği gibi gözlenmiştir. Bu durum birincil kristalitlerin erimesine ve kristalize edilmiş malzemenin tekrar erimesine atfedilmektedir [34]. Elektroeğrilmiş PCL/PHBV membran için ise hem $55.06{ }^{\circ} \mathrm{C}$ derecede bir pik, hem de $145.9{ }^{\circ} \mathrm{C}$ ve $155.60{ }^{\circ} \mathrm{C}$ derece olmak üzere iki pik gözlenmiştir. Bu değerlere bakıldığında, membran karışımının, hem PCL hem de PHBV içerdiği açık bir şekilde anlaşılmaktadır. 


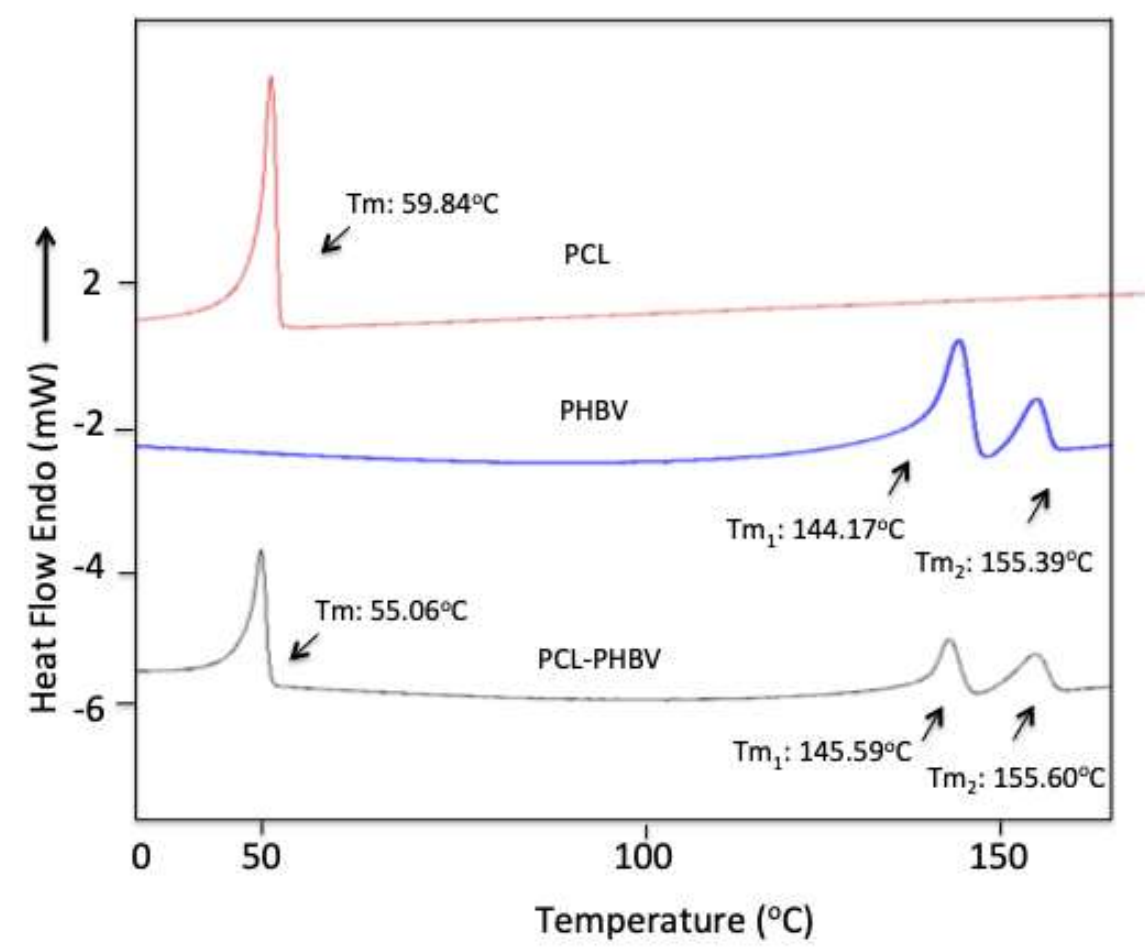

Şekil 2. Elektroeğrilmiş PCL, PHBV ve PCL/PHBV karışım membranlara ait DSC termogramları

\subsection{Morfolojik Analiz}

İdeal bir yara örtü malzemesinin, hasarlı deri dokusunun iyileşmesi için bölgeye göç eden hücrelerin yapışması ve çoğalmasını sağlayacak morfolojiye sahip olması büyük önem taşımaktadır. Ayrıca, yara bölgesindeki gaz geçirgenliğini sağlaması ve yara bölgesinden eksudatın uzaklaştırılması için birbiriyle bağlantılı gözenek yapıda olması gerekmektedir. Bunun dışında, yara örtü malzemesinin dış kısmının dışarıdan gelecek bakteri tehdidine karşı bir bariyer görevi görmesi beklenmektedir. Bu özelliklere sahip bir yara örtü malzemesi hazırlanması için en uygun yöntemlerden bir tanesi elektroeğirme yöntemidir. Elektroeğirme yönteminde kullanılan polimerin cinsi, molekül ağırlı̆̆ı, başlangıç polimer konsantrasyonu, polimer çözeltisinin viskozitesi ve yüzey gerilimi, uygulanan voltaj, iğne ucu kalınlığ ve toplayıcı ile iğne ucu arasındaki mesafe, çevresel koşullar gibi parametreler fiberlerin çaplarına ve morfolojilerine doğrudan etki ettiği birçok çalışmada gösterilmiştir. Bu bilgilerden yola çıkarak PCL ve PHBV karışımlarından boncuksuz yapıda ve homojen dağılmış fiberlere sahip membranların elde edilmesi için en uygun elektroeğirme parametreleri belirlenmiş ve bu çalışmalardan elde edilen elektroeğrilmiş membranların morfolojileri SEM ile incelenmiştir. Ayrıca fiber morfolojisine çözücünün etkisi incelenmiştir. Çözücü olarak kloroform kullanılarak elde edilen membranlar her ne kadar boncuksuz yapıda olsa da SEM görüntüleri ayrıntılı incelendiğinde fiberler çaplarının çok heterojen olduğu ve kloroform tamamen uzaklaşmadığından dolayı fiberler üzerinde kuyucuklar oluştuğu görülmektedir (Şekil 3A, B, C). Bu durum fiberlerin daha kırılgan olmasına sebep olacağı düşünülmektedir. $\mathrm{O}$ sebeple çözücü olarak $\mathrm{CHCl}_{3} / \mathrm{HFIP}$ karışımı ve HFIP tek başına kullanılarak polimer karışımı hazırlanmış ve elektroeğirme prosesine tabi tutulmuştur. Fiber morfolojisi incelendiğinde fiberler üzerinde o kırılgan yapının ortadan kalktığı gözlenmiş ve iki çözelti sistemi arasından fiber çapları ve gözenek yapılarının daha homojen olarak elde edildiği HFIP tek başına çözücü olarak kullanılarak hazırlanan membranlar bir sonraki aşama için seçilmiştir.

Yapılan ön çalışmalardan elde edilen bulgulara göre boncuksuz yapıda ve homojen fiberlere sahip membranların eldesi için PCL/PHBV ağırlıkça \%50:50 ve \% 75:25 olacak şekilde karıştırılmış ve çözelti hacimce $\% 15$ olacak şekilde $\mathrm{CHCl}_{3}, \mathrm{CHCl}_{3} / \mathrm{HFIP}$ (v/v, 50:50) ve HFIP çözücü sistemlerde hazırlanmıştır. Elektroeğirme parametreleri için ise en optimum koşullar iğne ucu-toplayıcı arası mesafe $15 \mathrm{~cm}$, uygulanan gerilim $15 \mathrm{kV}$ ve akış hızı ise $1 \mathrm{~mL} / \mathrm{h}$ olarak belirlenmiştir. Hazırlanan elektroeğrilmiş PCL, PHBV ve PCL/PHBV membranların karışım oranları Tablo 1'de verilmiştir. 
Tablo 1. Hazırlanan elektroeğrilmiş PCL, PHBV ve PCL/PHBV membranların \% karışım oranları ve ortalama

\begin{tabular}{|c|c|c|c|}
\hline PCL & PHBV & Çözücü & Ortalama Fiber Çapı \\
\hline 100 & 0 & $\mathrm{CHCl}_{3}$ & $2,116 \pm 0,350$ \\
\hline 50 & 50 & $\mathrm{CHCl}_{3}$ & $1,327 \pm 0,570$ \\
\hline 50 & 50 & $\mathrm{CHCl}_{3} / \mathrm{HFIP}(50: 50)$ & $1,141 \pm 0,200$ \\
\hline 50 & 50 & HFIP & $1,067 \pm 0,331$ \\
\hline 75 & 25 & $\mathrm{CHCl}_{3}$ & $1,373 \pm 0,561$ \\
\hline 75 & 25 & $\mathrm{CHCl}_{3} / \mathrm{HFIP}(50: 50)$ & $1,560 \pm 0,267$ \\
\hline 75 & 25 & HFIP & $0,933 \pm 0,186$ \\
\hline 0 & 100 & $\mathrm{CHCl}_{3}$ & Fiber gözlenmedi \\
\hline
\end{tabular}

Elektroeğrilmiş PCL ve PCL/PHBV karışım membranlarına ait SEM görüntülerinden (Şekil 3) fiberlerin toplayıcı üzerine kesintisiz ve homojen şekilde rastgele yayıldığı, herhangi bir boncuk yapısının yer almadığı görülmektedir. Ancak, \%100 PHBV membrana ait SEM görüntülerinde herhangi bir fiber yapısı gözlenmemiştir. SEM görüntüleri üzerinde farklı noktalardan rastgele seçilen 50 fiber kullanılarak gerçekleştirilen ölçümlerde membranları oluşturan fiberlerin ortalama çapları $1 \mu$ m ile 2,12 $\mu \mathrm{m}$ arasında bulunmuştur. Ortalama fiber çapları standart sapmaları ile birlikte Şekil 4'te sunulmuştur. Bu sonuçlara göre PCL/PHBV (75:25) karışımı olarak \%100 HFIP içerisinde hazırlanan membranına ait fiberlerin gerek morfolojisi gerekse fiber çapları göz önüne alındığında in vitro hücre çalışması için uygun bulunmuştur. 

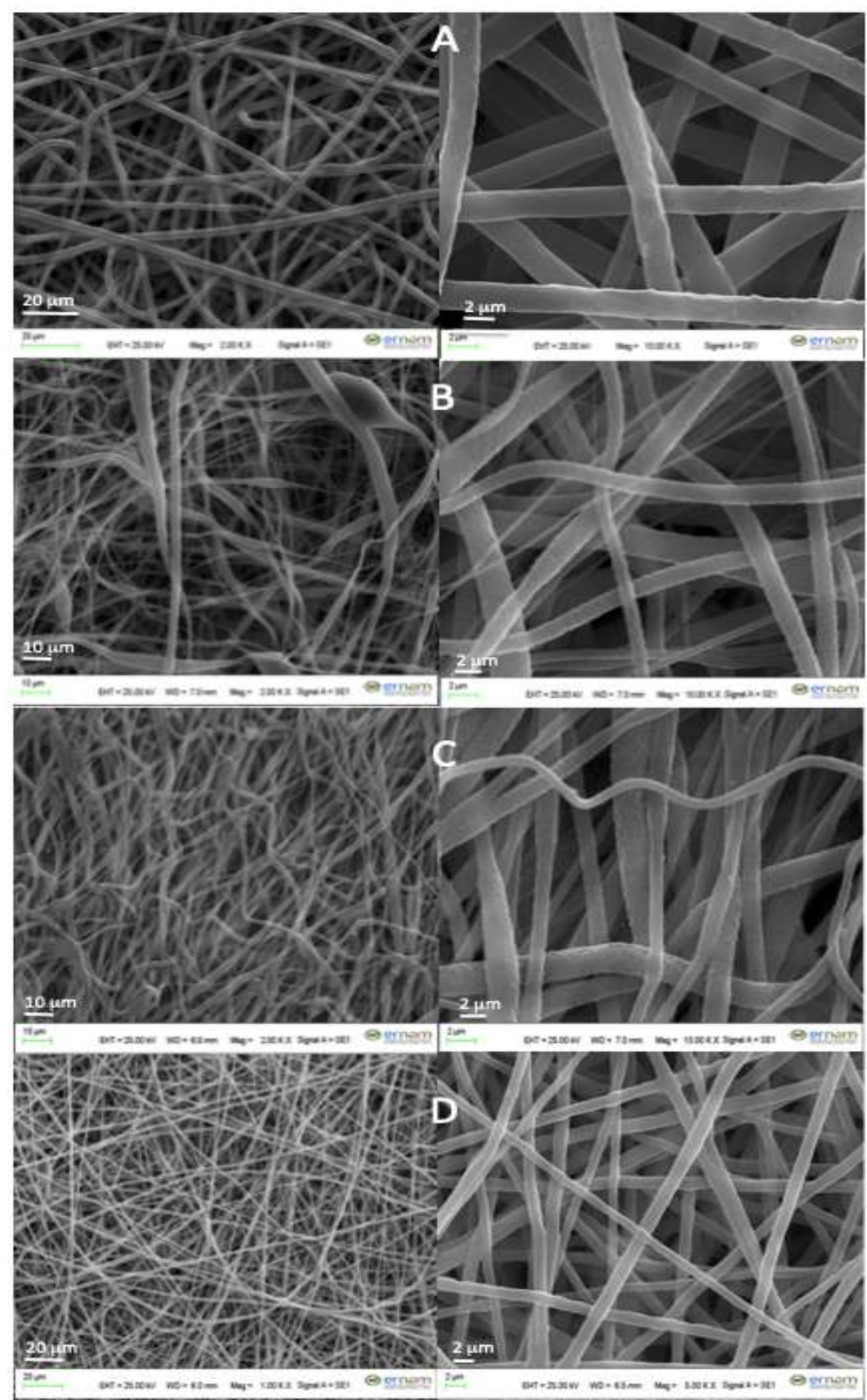

Şekil 3. Elektroeğrilmiş membranlara ait SEM görüntüleri $\mathbf{A})$ PCL $\left.\left(\mathrm{CHCl}_{3}\right), \mathbf{B}\right)$ PCL/PHBV (50:50, $\mathrm{CHCl}_{3}$ ), C) PCL/PHBV (75:25, $\mathrm{CHCl}_{3}$ ), D) PCL/PHBV (50:50, $\left.\mathrm{CHCl}_{3} / \mathrm{HFIP}\right)$, E) PCL/PHBV (50:50, HFIP), F) PCL/PHBV (75:25, $\left.\mathrm{CHCl}_{3} / \mathrm{HFIP}\right)$, G) PCL/PHBV (75:25, HFIP), H) PHBV $\left(\mathrm{CHCl}_{3}\right)$ 

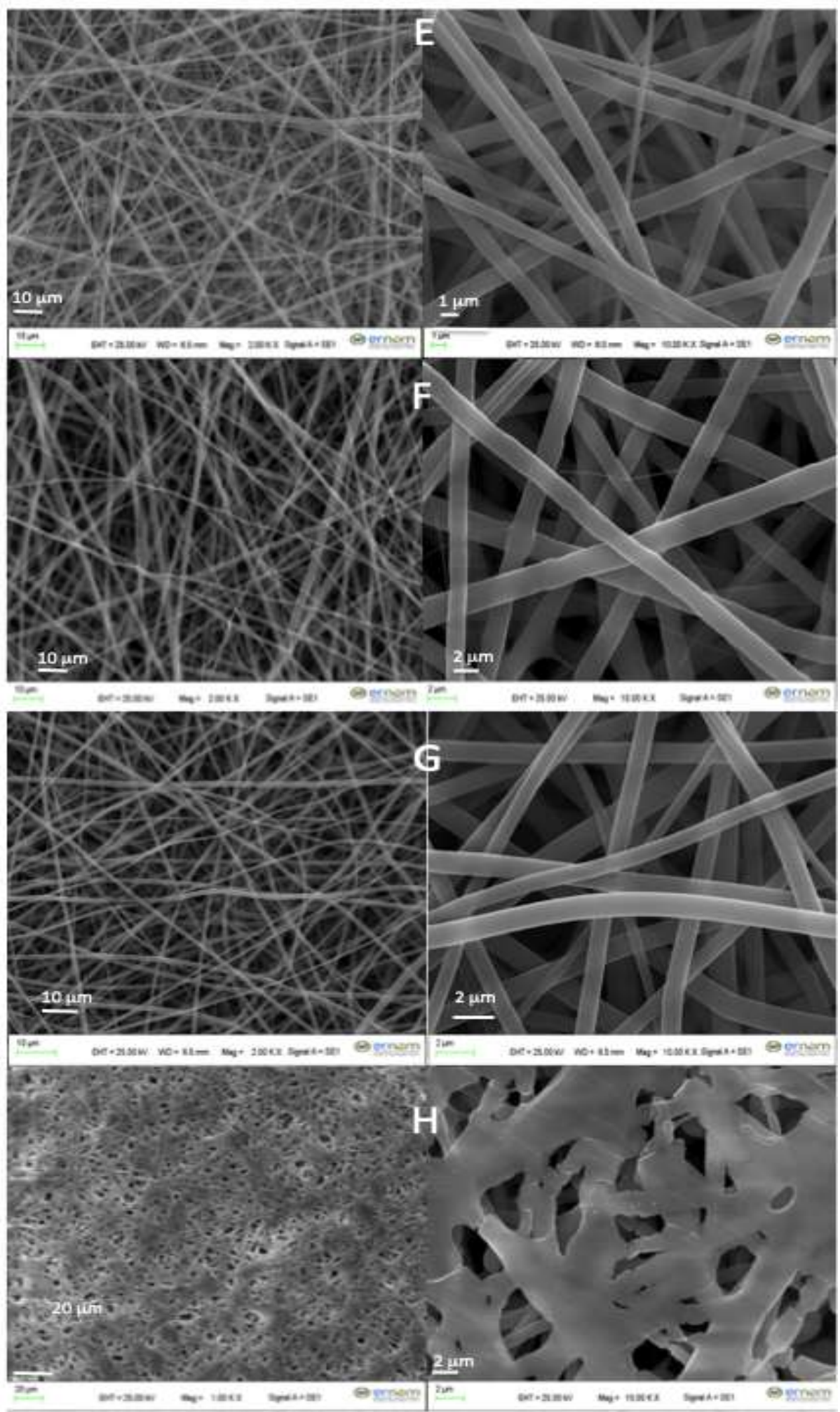

Şekil 3 (devamı). Elektroeğrilmiş membranlara ait SEM görüntüleri A) PCL $\left(\mathrm{CHCl}_{3}\right)$, B) PCL/PHBV (50:50, $\mathrm{CHCl}_{3}$ ), C) PCL/PHBV $\left(75: 25, \mathrm{CHCl}_{3}\right)$, D) PCL/PHBV (50:50, $\left.\mathrm{CHCl}_{3} / \mathrm{HFIP}\right)$, E) PCL/PHBV (50:50, HFIP), F) PCL/PHBV (75:25, $\left.\left.\mathrm{CHCl}_{3} / \mathrm{HFIP}\right), \mathbf{G}\right)$ PCL/PHBV (75:25, HFIP), H) PHBV $\left(\mathrm{CHCl}_{3}\right)$ 


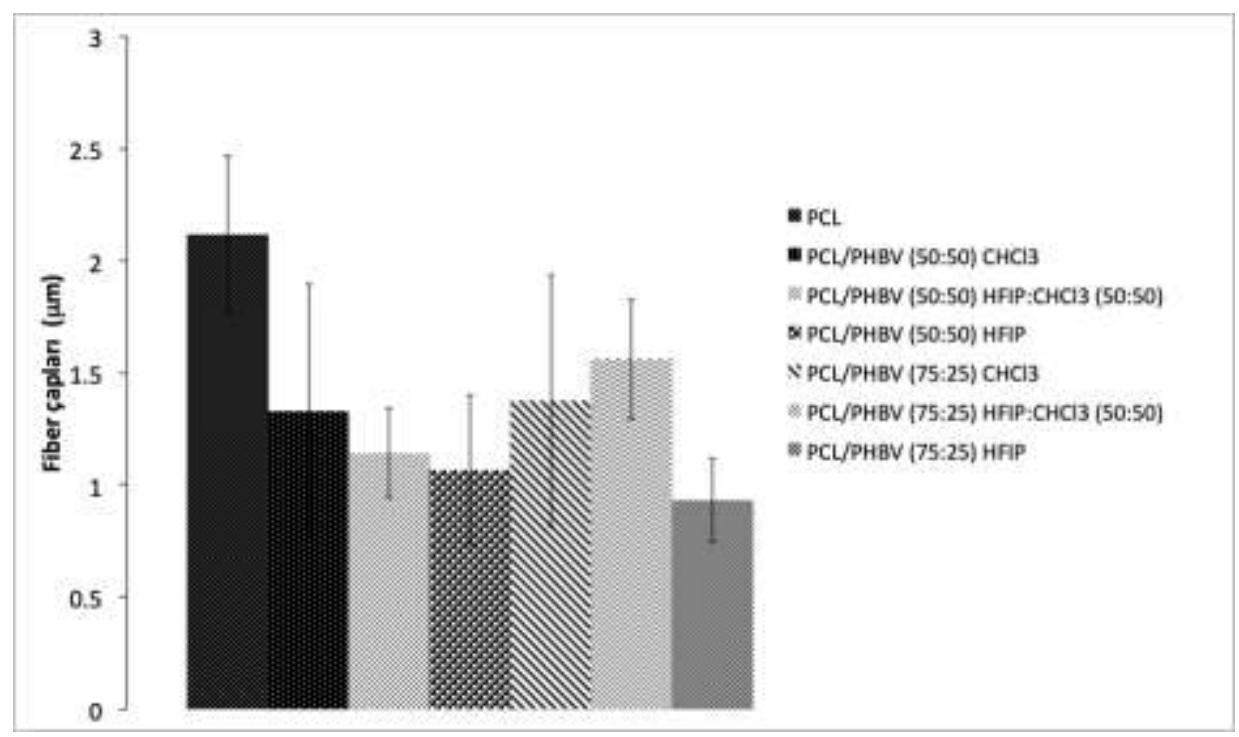

Şekil 4. Elektroeğrilmiş membranların ortalama fiber çapları

\subsection{Absorbsiyon Testi}

Yara bölgesinden eksudatın uzaklaştırılması için yüksek absorbsiyon kapasitesi, yara örtü malzemeleri için önemli ve kritik bir parametredir [21]. Çalışmada, çözücü uzaklaştırma yöntemi ile petri kapı üzerinde üretilen PCL/PHBV membran ile elektroeğrilmiş PCL/PHBV (75:25, HFIP) karışım membranının absorbsiyon kapasitesi ölçülmüş ve Şekil 5'te sunulmuştur. Şekilden de görüldüğü gibi elektroeğrilmiş membranın absorbsiyon kapasitesi yaklaşık \%407 olarak ölçülürken, petri kabı üzerinde çözücü uzaklaştırma yöntemi ile elde edilen elektroeğrilmemiş membranın sıvı tutma kapasite yaklaşık \%3 olarak ölçülmüştür. Aradaki farkın bu kadar yüksek olması elektroeğrilmiş membranın birbiriyle bağlantılı gözenekli fibroz yapısından kaynaklanmaktadır.

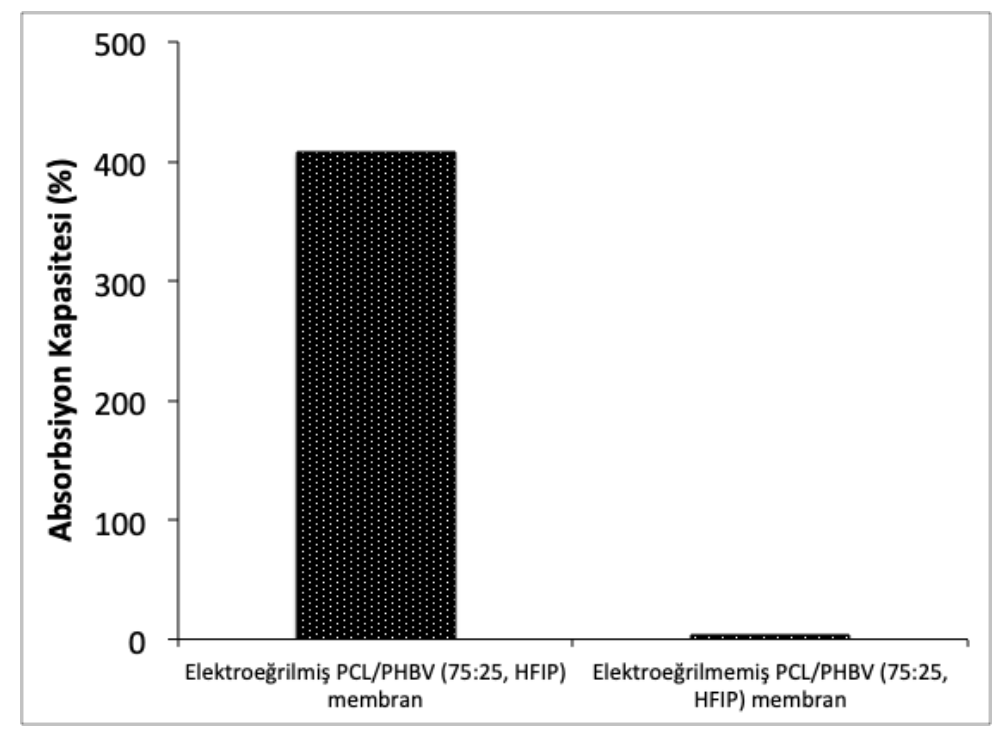

Şekil 5. Absorbsiyon Kapasite Testi Sonuçları

\subsection{In vitro Hücre Kültürü ve Sitotoksisite Testi}

Hücre canlılığı MTT testi ile 24, 48 ve 72 . saat için ölçülmüştür. MTT testinde, sarı tetrazoliumun yalnız canlı hücreler içerisinde mor formazan kristallerine dönüşmekte ve bu dönüşüm prosesi her bir kuyucuktaki canlı hücreleri göstermektedir [35]. Elektroeğrilmiş PCL ve PCL/PHBV (75:25, HFIP) membranları üzerine ekilmiş insan fibroblast hücrelerinin 24,48 ve 72 . saat hücre canlılık sonuçları Şekil 6'da verilmiştir. Şekilden de görüldüğü gibi hücrelerin membran yüzeylerine tutunduğu ve canlılık 
oranlarının \%92'in üzerinde olduğu görülmektedir. Elektroeğrilmiş PCL/PHBV (75:25, HFIP) membranına ekilen hücrelerin elektroeğrilmiş PCL membrana kıyasla canlılık oranlarının daha yüksek olduğu görülmüştür. $\mathrm{Bu}$ artışın, sentetik bir polimer olan PCL'in tek başına kullanılmasından ziyade doğal bir polimer olan PHBV ile birlikte kullanımının sinerjik bir etki oluşturduğu ve 3 boyutlu olarak hücre canlılığı açısından daha etkili olduğunu göstermektedir.

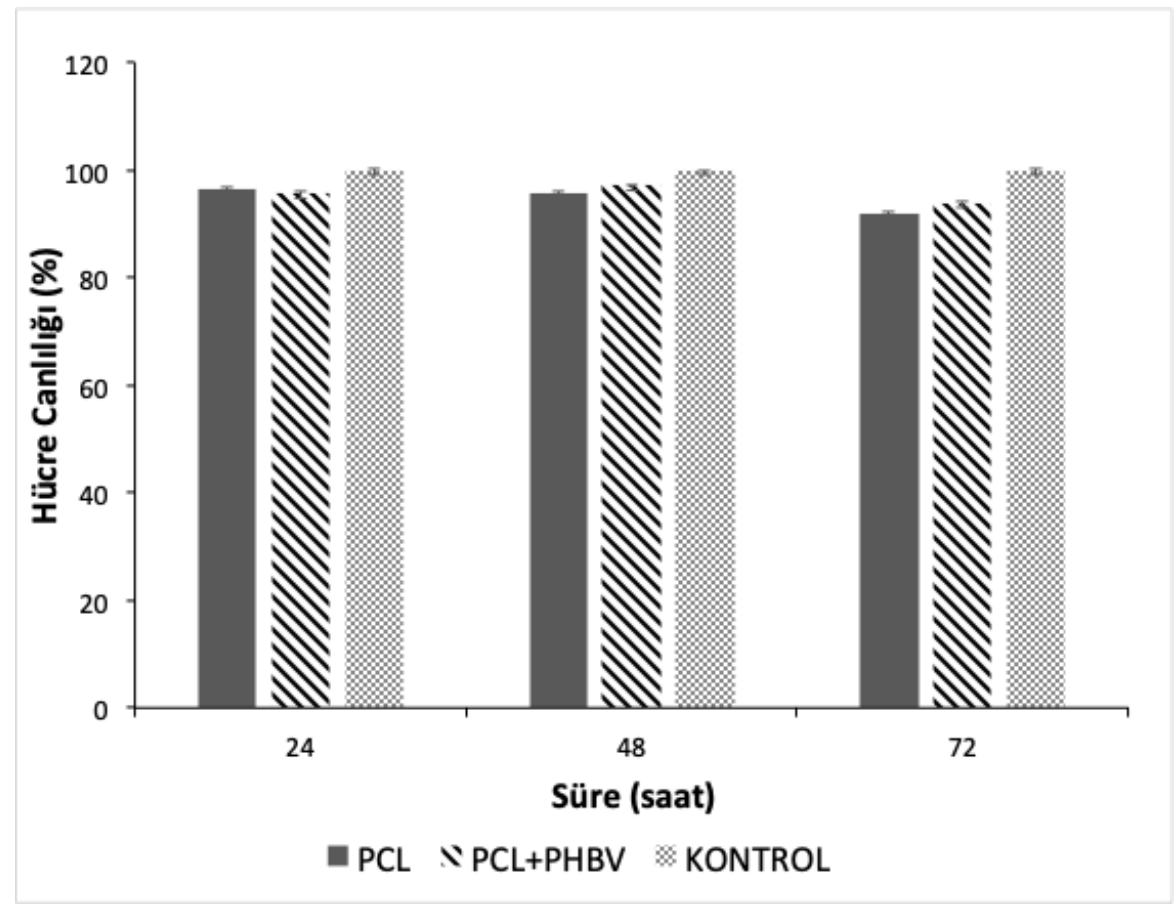

Şekil 6. Hücre canlılığı ve sitotoksisite testi, x ekseni süre (saat)

\subsection{Hücre Yapışması}

Elektroeğrilmiş PCL ve PCL/PHBV (75:25, HFIP) membranları üzerine ekilmiş insan fibroblast hücrelerinin 36, 72 ve 120. saat hücre yapışmalarına ait SEM görüntüleri Şekil 7 ve 8 'de sunulmuştur. SEM görüntülerinden de açıkça gözlemlendiği gibi PCL/PHBV (75:25, HFIP) membranına ekilen hücrelerin 120. saat sonunda neredeyse tüm membran yüzeyini kapladığı ve PCL membrana orana göre daha fazla hücrenin yayıldığı görülmüştür. Bunun sebebinin PCL/PHBV membranın PCL membrana oranla 3 boyutlu morfolojik yapısının hücrelerin fiberler arasında yayılmasına desteleyecek özellikte olduğu değerlendirilmiştir. 

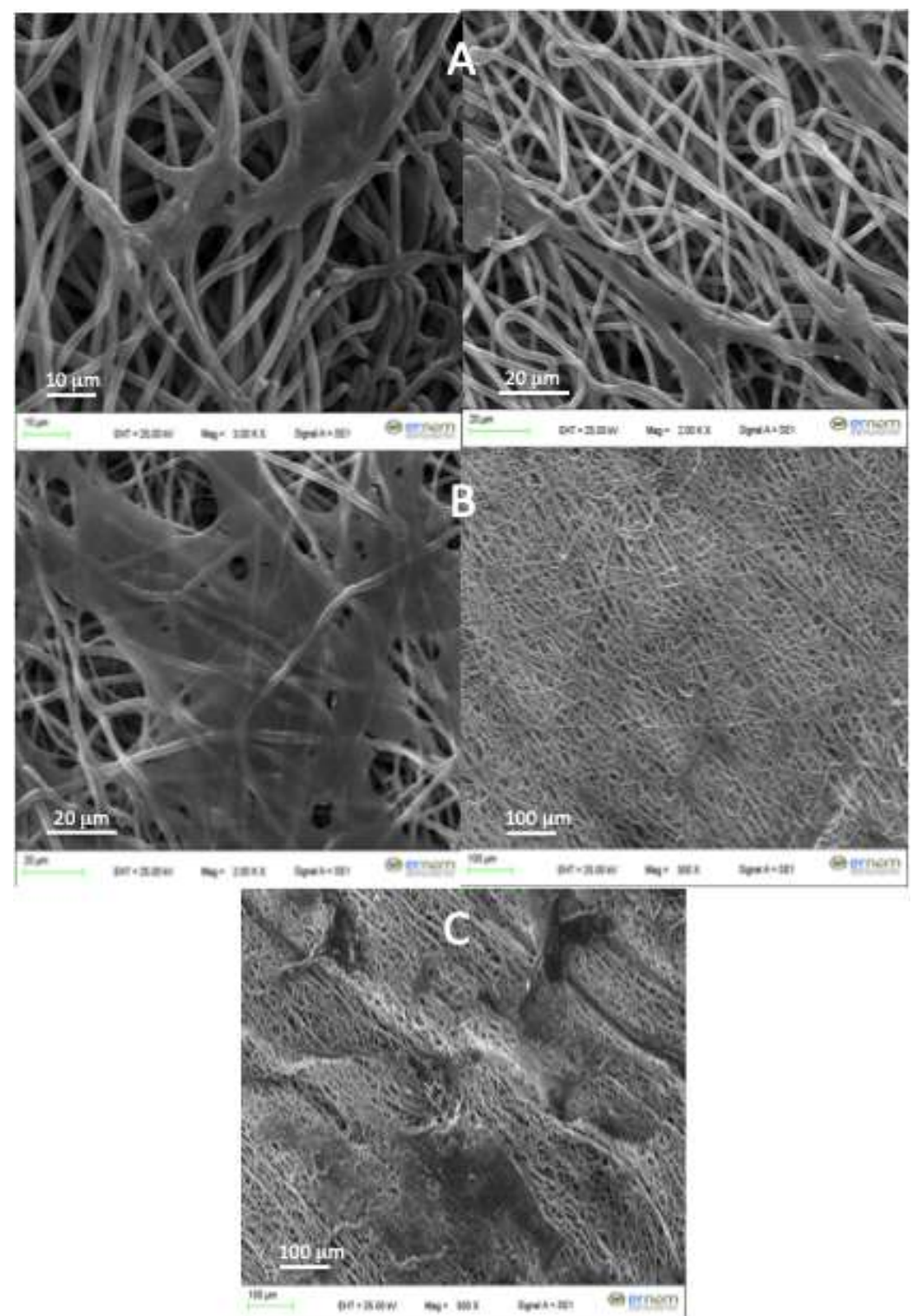

Şekil 7. Hücre yapışması SEM görüntüleri A) PCL $\left(\mathrm{CHCl}_{3}\right)$, 36. saat, B) PCL $\left(\mathrm{CHCl}_{3}\right)$, 72. saat, C) $\mathrm{PCL}\left(\mathrm{CHCl}_{3}\right), 120$. saat 

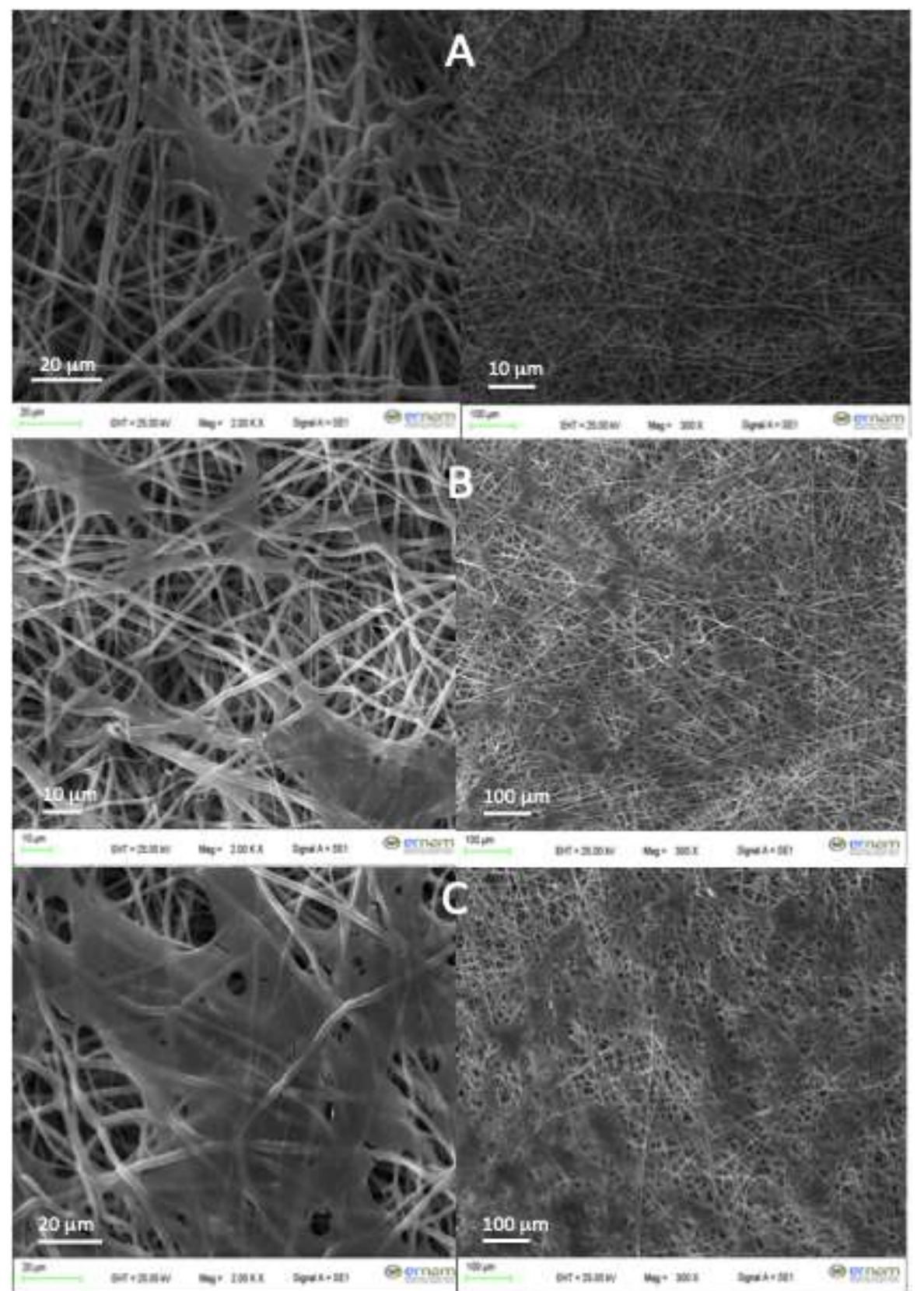

Şekil 8. Hücre yapışması SEM görüntülere A) PCL/PHBV (75:25, HFIP), 36. saat, B) PCL/PHBV (75:25, HFIP), 72. saat, C) PCL/PHBV (75:25, HFIP), 120. saat

\section{Sonuç ve Öneriler}

Bu çalışmada, yara örtü malzemesi olarak değerlendirmek üzere PCL, PHBV ve PCL/PHBV karışımları ağırlıkça farklı oranlarda $(100: 0,50: 50,75: 25,0: 100)$ ve farklı çözücüler kullanılarak $\left(\mathrm{CHCl}_{3}\right.$, $\mathrm{CHCl}_{3} / \mathrm{HFIP}(\mathrm{v} / \mathrm{v}, 50: 50)$ ve HFIP) elektroeğirme işlemine tabi tutularak fibroz yapıda membranlar üretilmiştir. Elde edilen membranların kimyasal analizi FT-IR ile termal analizi ise DSC ile gerçekleştirilmiştir. Bulunan sonuçlar literatürde yapılan benzer çalışmalarda bulunan sonuçlarla uyumlu olduğu tespit edilmiştir. Membranların yapısal analizi ise SEM ile incelenmiştir. SEM görüntülerinden elektroeğrilmiş membranların boncuksuz yapıda ve rastgele dağılan fiberlere sahip olduğu ve membranların ortalama fiber çaplarının $1 \mu \mathrm{m}$ ile $2,12 \mu \mathrm{m}$ arasında değiştiği gösterilmiştir. Membranlar arasında PCL/PHBV (75:25, HFIP) 0.933 $\pm 0.186 \mu \mathrm{m}$ fiber çapı ile en küçük fiber çapına sahip membran olarak bulunmuştur. Bunun yanı sıra bu membrana ait fiber dağılımı diğer membranlara kıyasla daha homojen olduğu belirlenmiştir. Elektroeğrilmiş PCL/PHBV (75:25, HFIP) membranın absorbsiyon kapasitesi ayrıca ölçülmüş ve \%407 gibi yüksek bir sıvı tutma kapasitesine sahip olduğu 
gösterilmiştir. Elektroeğrilmiş PCL ve PCL/PHBV (75:25, HFIP) membranları üzerine insan fibroblast hücreleri ekilmiş, hücre canlılığ 1 ve toksisite davranışları incelenmiştir. Elde edilen sonuçlara göre her iki membranın da toksik özellik göstermediği ve 24,48 ve 72 . saat için hücre canlılık yüzdeleri PCL membran için yaklaşık \%92 ve PCL/PHBV (75:25, HFIP) membran için ise yaklaşık \%97 olduğu belirlenmiştir. Membranların üzerine ekilen hücrelerin 36, 72 ve 120. saat için çoğalmaları SEM ile gösterilmiştir. Buna göre PCL/PHBV (75:25, HFIP) membranı üzerindeki hücre çoğalmasının PCL membranına kıyasla daha yüksek olduğu gösterilmiştir. Çalışmada elde edilen sonuçlara göre, doğru elektroeğirme parametreleri ve çözücü sistemleri kullanıldığında PCL ve PHBV'nin tek başına kullanılmasından ziyade karışım olarak kullanılmalarının sinerjik bir etki oluşturduğu ve elektroeğrilmiş PCL/PHBV karışım membranlarının yara örtü malzemesi olarak çok iyi bir aday olduğu değerlendirilmiştir.

\section{Kaynaklar}

[1] Kuppan P., Kirthanashri S.V., Dhakshinamoorthy S., Uma M.K., Swaminathan S. 2011. Development of Poly(3-hydroxybutyrate-co-3-hydroxyvalerate) Fibers for Skin Tissue Engineering: Effects of Topography, Mechanical, and Chemical Stimuli. Biomacromolecules, 12 (9): 3156-3165.

[2] Zonari A., Cerqueira M.T., Novikoff, S., Goes A.M., Marques, A.P., Correlo, V.M., Reis, R.L. 2014. Poly(hydroxybutyrate-co-hydroxyvalerate) Bilayer Skin Tissue Engineering Constructs with Improved Epidermal Rearrangement. Macromolecular Bioscience, 14 (7): 977-990.

[3] Du L., Xu H.Z., Li T., Zhang Y., Zou F.Y. 2017. Fabrication of Ascorbyl Palmitate Loaded Poly(caprolactone)/Silver Nanoparticle Embedded Poly(vinyl alcohol) Hybrid Nanofibre Mats as Active Wound Dressings: Via Dual-Spinneret Electrospinning. RSC Advances, 7 (50): 31310 31318.

[4] Augustine R., Anto Dominic E., Reju I., Kaimal B., Kalarikkal N., Thomas S. 2015. Electrospun Poly(e-caprolactone)-Based Skin Substitutes: In Vivo Evaluation of Wound Healing and The Mechanism of Cell Proliferation. Journal of Biomedical Materials Research Part B: Applied Biomaterials, 103 (7): 1445-1454.

[5] Sahana T.G., Rekha, P.D. 2018. Biopolymers: Applications in Wound Healing and Skin Tissue Engineering. Molecular Biology Report, 45 (6): 2857-2867.

[6] Moura D., Souza M.T., Liverani L., Rella G., Luz G.M., Mano J.F., Boccaccini A.R. 2017. Development of A Bioactive Glass-Polymer Composite for Wound Healing Applications. Materials Science and Engineering C, 76: 224-232.

[7] Sundaramurthi D., Krishnan U.M., Sethuraman S. 2014. Epidermal Differentiation of Stem Cells on Poly(3-hydroxybutyrate-co-3-hydroxyvalerate) (PHBV) Nanofibers. Annals of Biomedical Engineering, 42 (12): 2589-2599.

[8] Lee J.M., Chae T., Sheikh F.A., Ju H.W., Moon B.M., Park H.J., Park Y.R., Park C.H. 2016. Three Dimensional Poly( $\varepsilon$-caprolactone) and Silk Fibroin Nanocomposite Fibrous Matrix for artificial Dermis. Materials Science and Engineering: C, 68: 758-67.

[9] MacEwan M.R., Macewan S., Kovacs T.R., Batts J. 2017. What Makes the Optimal Wound Healing Material? A Review of Current Science and Introduction of a Synthetic Nanofabricated Wound Care Scaffold, 9 (10): 1736-1748.

[10] Biazar E. 2017. Application of Polymeric Nanofibers in Medical Designs, Part I: Skin and Eye. International Journal of Polymeric Materials and Polymeric Biomaterials, 66 (10): 521-531.

[11] Miguel S.P., Figueira D.R., Simões D., Ribeiro M.P., Coutinho P., Ferreira P., Correia I.J. 2018. Electrospun Polymeric Nanofibres as Wound Dressings: A Review, Colloids Surfaces B Biointerfaces, 169: 60-71.

[12] Lv F., Wang J., Xu P., Han Y., Ma H., Xu H., Chen S., Chang J., Ke Q., Liu M., Yi Z., Wu C. 2017. A Conducive Bioceramic/Polymer Composite Biomaterial for Diabetic Wound Healing. Acta Biomaterialia, 60: 128-143.

[13] Bölgen N., Menceloğlu Y.Z., Acatay K., Vargel I., Pişkin E. 2005 In Vitro and in Vivo Degradation of Non-Woven Materials Made of Poly(E-Caprolactone) Nanofibers Prepared by Electrospinning Under Different Conditions. Journal of Biomaterials Science, Polymer Edition, 16 (12): 1537-1555. 
[14] Rather H.A., Thakore R., Singh R., Jhala D., Singh S., Vasita R. Antioxidative Study of Cerium Oxide Nanoparticle Functionalised PCL-Gelatin Electrospun Fibers for Wound Healing Application. Bioactive Materials, 3 (2): 201-211.

[15] Yuan J., Geng J., Xing Z., Shim K-J., Han I., Kim J-C., Kang I-K., Shen J. 2015. Novel Wound Dressing Based on Nanofibrous PHBV-Keratin Mats. Journal of Tissue Engineering and Regenerative Medicine, 9: 1027-1035.

[16] Tohidi S., Ghaee A., Barzin J. 2016, Preparation and Characterization of Poly(lactic-co-glycolic acid)/Chitosan Electrospun Membrane Containing Amoxicillin-Loaded Halloysite Nanoclay. Polymers for Advanced Technologies, 27: 1020-1028.

[17] Dias J.R., Granja P.L., Bártolo P.J. 2016. Advances in Electrospun Skin Substitutes. Progress in Materials Science, 84: 314-334.

[18] Zhang W., Ronca S., Mele E. 2017. Electrospun Nanofibres Containing Antimicrobial Plant Extracts. Nanomaterials, 7 (2): 42-59.

[19] Patil J.V., Mali S.S., Kamble A.S., Hong C.K., Kim J.H., Patil P.S. 2017. Electrospinning: a Versatile Technique for Making of 1D Growth of Nanostructured Nanofibers and Its Applications: An Experimental Approach. Applied Surface Science, 423: 641-674.

[20] Chen S., Liu B., Carlson M.A., Gombart A.F., Reilly D.A., Xie J. 2017. Recent Advances in Electrospun Nanofibers for Wound Healing. Nanomedicine, 12: 1335-1352.

[21] Liu M., Duan X., Li Y., Yang D., Long Y. 2017. Electrospun Nano Fibers for Wound Healing. Materials Science and Engineering C, 76: 1413-1423.

[22] Mir M., Ali M.N., Barakullah A., Gulzar A., Arshad M, Fatima S., Asad M. 2018. Synthetic Polymeric Biomaterials for Wound Healing: A Review. Progress in Biomaterials, 7 (1): 1-21.

[23] Siddiqui N., Asawa S., Birru B., Baadhe R., Rao S. 2018. PCL-Based Composite Scaffold Matrices for Tissue Engineering Applications. Molecular Biotechnology, 60: 506-532.

[24] Thanh Tra N., Minh H.H., Nam T.M.H., Thien D.B.T., Hoai, N.T.T., Phuoc, T.V., Thai D.M., Hai, N.D., Toi, V.V., Hiep, N.T. 2018. Optimization and Characterization of Electrospun Polycaprolactone Coated with Gelatin-Silver Nanoparticles for Wound Healing Application. Materials Science \& Engineering C, 91: 318-329.

[25] Martins A.F., Facchi S.P., da Câmara P.C.F., Camargo S.E.A., Camargo C.H.R., Popat K.C., Kipper M.J. 2018. Novel Poly( $\varepsilon$-Caprolactone)/Amino-Functionalized Tannin Electrospun Membranes as Scaffolds for Tissue Engineering. Journal of Colloid and Interface Science, 525: 21-30

[26] Mutlu G., Calamak S., Ulubayram K., Guven E. 2018. Curcumin-Loaded Electrospun PHBV Nanofibers as Potential Wound-Dressing Material. Journal of Drug Delivery Science and Technology, 43: 185-193.

[27] Veleirinho B., Coelho D.S., Dias P.F., Maraschin M., Ribeiro-do-Valle R.M., Lopes-da-Silva J.A. 2012. Nanofibrous Poly(3-hydroxybutyrate-co-3-hydroxyvalerate)/Chitosan Scaffolds for Skin Regeneration. International Journal of Biological Macromolecules, 51 (4): 343-350.

[28] Shishatskaya E.I., Nikolaeva E.D., Vinogradova O.N., Volova T.G. 2016. Experimental Wound Dressings of Degradable PHA for Skin Defect Repair. Journal of Materials Science: Materials in Medicine, 27 (11): 165.

[29] Adeli-Sardou M., Yaghoobi M.M., Torkzadeh-Mahani M., Dodel M. 2019. Controlled Release of Lawsone from Polycaprolactone/Gelatin Electrospun Nano Fibers for Skin Tissue Regeneration. International Journal of Biological Macromolecules, 124: 478-491.

[30] Ehterami A., Salehi M., Farzamfar S., Vaez A., Samadian H., Sahrapeyma H., Mirzaii M., Ghorbani S., Goodarzi A. 2018. In Vitro and In Vivo Study of PCL/COLL Wound Dressing Loaded with Insulin-Chitosan Nanoparticles on Cutaneous Wound Healing in Rats Model. International Journal of Biological Macromolecules, 117: 601-609.

[31] İşoğlu İ.A., Demirkan C., Şeker M.G., Tuzlakoğlu K., İşoğlu S.D. 2018. Antibacterial Bilayered Skin Patches Made of HPMA and Quaternary Poly(4-Vinyl Pyridine). Fibers and Polymers, 19 (11): 2229-2236.

[32] K-Hasuwan P.R., Pavasant P., Supaphol P. 2011. Effect of the Surface Topography of Electrospun Poly(E-caprolactone)/Poly(3-hydroxybuterate-co-3-hydroxyvalerate) Fibrous Substrates on Cultured Bone Cell Behavior. Langmuir, 27: 10938-10946. 
[33] Malikmammadov E., Tanir T.E., Kiziltay A., Hasirci V., Hasirci N. 2018. PCL and PCL-Based Materials in Biomedical Applications. Journal of Biomaterials Science, Polymer Edition, 29 (79): 863-893.

[34] Del Gaudio C., Ercolani E., Nanni F., Bianco A. 2011. Assessment of Poly( $\varepsilon$ caprolactone)/Poly(3-hydroxybutyrate-co-3-hydroxyvalerate) Blends Processed by Solvent Casting and Electrospinning. Materials Science and Engineering A, 528 (3): 1764-1772.

[35] Chanda A., Adhikari J., Ghosh A., Roy S., Thomas S., Datta P., Saha P. 2018. Electrospun Chitosan/Polycaprolactone-Hyaluronic Acid Bilayered Scaffold for Potential Wound Healing Applications. International Journal of Biological Macromolecules, 116: 774-785. 